This item is the archived peer-reviewed author-version of:

Does mosque location matter? Mosque and Islamic shops in the European context

\title{
Reference:
}

El Boujjoufi Mohamed, Mustafa Ahmed, Teller Jacques.- Does mosque location matter? Mosque and Islamic shops in the European context Journal of Islamic Marketing - ISSN 1759-0841 - Bingley, Emerald group publishing Itd, (2021)19 p.

Full text (Publisher's DOI): https://doi.org/10.1108/JIMA-01-2021-0007 
Preprint, the final version, of the article that has been transferred to the journal's production team.

To cite this article: El Boujjoufi, M., Mustafa, A. and Teller, J. (2021), "Does mosque location matter? Mosque and Islamic shops in the European context", Journal of Islamic Marketing, Vol. ahead-of-print No. ahead-ofprint.

https://doi.org/10.1108/JIMA-01-2021-0007

\section{Does mosque location matter? Mosque and Islamic shops in the European context.}

\section{Purpose:}

Mosques influence the surrounding neighborhoods' demographic patterns and motivate investors to establish new businesses and commercial activities. This study explores the impact of the mosque on the emergence of new businesses. Furthermore, we examine the demography of neighborhoods in which mosques are located.

\section{Design/methodology/approach:}

This study opts for an exploratory study using a retrospective analysis approach to explore the mosque's impact on the social and functional aspects of neighborhoods. The emerging shops around mosques in the city of Liège (Belgium) are analyzed using a logistic regression model. The criterion for the location of Islamic shops was cross-referenced with other variables, such as distance from the center, proximity to supermarkets and shopping malls, distance from the mosque, socio-economic variables (immigration, income nationalities, etc.), and bus accessibility data. Several zones around mosques, ranging from 100 to 1000 meters, are established to examine the correlation between types of businesses and distance to the mosque. Five types of businesses are identified: regular trade, light semi-regular trade, heavy semi-regular trade, Horeca, and services. Islamic shops are identified based on on-site observations and interviews and classified by type.

\section{Findings:}

The results show that mosques significantly impact the establishment of new businesses in the surrounding urban space (especially Islamic shops). In terms of the types of Islamic businesses surrounding the mosques, we found a strong presence of "Horeca" (cafes, restaurants, and snack bars), and "Light semi-regular trade" (mainly personal care).

\section{Originality/value :}

This study is one of the few studies that fulfill the need to understand the role of the mosque location in European cities, focusing on its impact on Islamic shops. 


\section{Introduction}

This paper focuses on the location of business activities oriented towards the Muslim community. This community's expansion within the European urban landscape has triggered population growth, which has contributed to an increase in the number of mosques, gathering places for prayer and worship, in the European public space. Muslims have thus contributed to the emergence of specific urban geography that challenges the social representation of the relationship between private and public spheres and the organization and structuring of public space (Conti, 2012; Göle, 2011). Islamic worship places have attracted other functions and activities, such as Islamic or Arabic language schools, libraries, restaurants, cafés, and markets. When looking at stores providing goods and services to Muslims (Islamic shops), the entrepreneur's background affects his business because religion is one of the central pillars on which migrants build their individual and collective identity (Peach, 2006; Saint-Blancat, 2002). The literature lacks a standard definition of ethnic business activity and even more so for ethnic businesses oriented towards the Muslim community (this study's focus). Indeed, there is no real consensus in the scientific community in this regard, even though several researchers have already tried to define the concept (Haberfellner et al., 2000; Light \& Gold, 2000; Peñaloza, 2018; Rossiter \& Chan, 1998; Waldinger, 1995; Waldinger et al., 1990).

The term "ethnic" has emerged to refer to contemporary urban phenomena (Rudder, 2002) and to define a culturally distinct group among the majority population (Kaplan, 1997). In terms of "ethnic trade", the word is associated with all cultural goods involving general nourishment, but not just-food. This commerce type is expanding to meet demands for clothing, body care, jewelry, housing, and other services (Dassetto, 2013). Kesteloot (1987) considers ethnic commerce to be culturally distinct from the majority in terms of its owners, employees, and customers. For Guillon (1986), the term is used to represent a trade practiced by certain ethnic groups for their community. It is a process that allows migrants of different origins and generations to practice this commercial activity. This practice remains very similar from one ethnic group to another and from one period to another (Barou, 1999).

Some researchers (e.g., Ma Mung \& Guillon, 1986; Simon \& Ma Mung, 1990) have considered commerce to be ethnic when the trader is of foreign origin. Ma Mung, Body-Gendrot, \& Hodeir (1992) completed this definition by adding the ethnic solidarities on which the trader relies. Wang and Lo (2007) added the cultural marking of the product mix and presentation, the decor, the sign, the atmosphere of the shop, and the language used. Gradually, investment in ethnic trade has filled niches vacated due to business evolution towards a concentration in large entities (shopping centers and galleries) and to the aging of indigenous traders, known as a substitution phenomenon (Waldinger, 1995).

Ethnic businesses are not necessarily businesses run by foreigners. A large proportion of them are run (or activated) by citizens, who have the country's nationality, even if they are immigrants 
(Battegay, 2011). The term "ethnic enterprise", which does not mean foreign enterprise, originates from research that has differentiated between ethnicity and ethnic, which leads to these trades being regarded as indigenous productions of the host society and not as imported or transplanted culture (Martiniello, 1995). Since the definition remains vague according to the criteria used, one can capture a commerce's culture by the person operating it (the trader), by the offered services and products, and by the majority of the clientele.

This study seeks to better understand the rationale of ethnic business locations by applying several criteria. The central question of this research is, "Is there a significant link between ethnically oriented business for Muslim communities and the presence of mosques?". To answer this question, this study follows a retrospective analysis approach to explore the mosque's impact on the social and functional aspects of neighborhoods. This study focuses on the city of Liège in Belgium. The presence of the Muslim community in the urban area, the presence of shopping centers, hypermarkets, and mosques, and many other criteria are therefore taken into consideration.

\section{Literature review}

Throughout time, migration has been an essential human prerequisite and a crucial constituent of economic development and human well-being. Migration is a decision that impacts the welfare of the household, the local community, and the whole economy in various ways (Azam \& Gubert, 2006).

The organization of an ethnic business directly relates to the owner's ethnicity and background. In this context, ethnicity is a crucial characteristic in pinpointing these groups. The organization of an ethnic business draws its strength from the family and community bond (Ma Mung, BodyGendrot, and Hodeir, 1992). Most ethnic business entrepreneurs tend to belong to groups with a strong sense of collective identity and a common interest (Barou, 1999). These ethnic entrepreneurial assemblies are related to the private sphere and characterized by specific features that differentiate them from others that have succeeded due to several factors depending on the setting and governmental procedures.

The ethnic economy has been a frequently investigated subject (Jones et al., 2000; Mung, 2015). As previously mentioned, there are several definitions concerning this subject matter, and they may differ from one ethnic group to another and from one country to another. Muslim entrepreneurs, for example, have risen in Europe in the past decades as a means to create an environment that welcomes Islamic practices.

Most studies that have analyzed this type of business have focused on the sociological aspects related to the study of ethnic trade and migration by using qualitative rather than quantitative 
approaches. The main contribution of this paper is to study the locations of business activities oriented towards the Muslim community through a quantitative approach at the city level.

\subsection{Islamic shops in the mosque's radius}

The presence of Islam in the European public space has been progressively reinforced in all of its components. Under the impetus of a claim to identity, it has gone from minor visibility to a much more marked presence (Allievi, 2009; Cesari, 2005a; Dassetto, 1996). The mosque for Muslims represents a guidance beacon, as the ritual of prayer (the second pillar of Islam) provides rhythm to the believer's daily life. Generally, mosques in Europe are located in marginal areas, away from city centers and in the periphery (industrial uses with limited access), in buildings that were not initially designed for worship purposes (Arab, 2013; Gale, 2008; Kuppinger, 2011). The urban segregation of mosques may reinforce Muslims' social marginalization, and conversely, better integration of mosques within the city would improve their acceptance (Schinkel, 2009; Schmitt, 2003).

\subsection{The allocation of Mosques}

Population growth (Manço \& Kanmaz 2005), high mosque attendance (Dassetto, 2013), and the value that worshippers ascribe to the place of worship (Gagnon \& Germain, 2002) are the main factors in the operation of mosques in the European urban landscape. Every year, Islam holds a greater place in Western cities' spaces (Allievi, 2010, 2014; Torrekens, 2007). To date, extensive work on Islamic worship places in Europe has been devoted to the socio-political dimension while referring to debates related to immigration, integration of the Muslim population (Allen et al., 2007; Allievi, 2003; Behloul et al., 2014; Fadil et al., 2010; Manço \& Amoranitis, 2005; Maussen, 2006, 2009; Torrekens, 2009), or the conflicts generated by the allocation of mosques in the public space (Germain et al., 2008; Jonker, 2005; Landman \& Wessels, 2005; McLoughlin, 2005). The mosque plays a vital role in Muslims' social and political organization at both the local and national levels (Galembert, 1995). It is a structure that guarantees a certain religious and cultural continuity while establishing territory in time and space (Dassetto, 1996). Perceived as a kind of refuge and meeting place, the mosque in its socio-cultural role can indeed adopt these functionalities (Maussen, 2009). This analysis will study the relationship between the allocation of these places of worship and the ecosystem created around them, recognizing that this integration occurs in a landscape of which they have been a part for only a few decades. This organization in the urban space is characterized by mass gravitation around a core (the mosque, in our case) and draws its fruits from the essays of H. Lefebvre (1970), who proposed a profound

renewal of urban analysis and understood the city as a "spatial object". This enables us to grasp socio-spatial dynamics and how urban society is organized. 


\subsection{Mosque's functions for different activities}

Mosques in Europe serve as community centers that are intended to be multi-functional (Conti, 2016). It is interesting to note that some events in mosques are also organized with and for nonMuslims (Cesari, 2005a). On this basis, other functions have been included in the mosque, such as Islamic schools, Islamic bookshops, cafés, restaurants, commerce, hairdressers, and many others, while creating an urban ecosystem revolving around the place of worship. By "ecosystem", we mean the reciprocal interaction between different parts and components that organize themselves to form a unit (Marín, 1997). These specific economic activities of producing and marketing products make it possible to respect the Islam principles and disseminate their Muslim thought. These establishments create a parallel universe to the (existing) world of cities with these streets and landmarks. This phenomenon has become an essential avenue for Muslim investors (Dassetto, 2013). Business activity facilitates the organization in Muslims' daily lives and the fulfillment of their obligations, namely, the practice of faith.

Muslims, in general, have adopted this issue of ethnic economy in Halal practices, and an ethnoreligious universe has emerged, allowing Muslims to translate their faith aspect into daily life. By halal practices, we mean any use or rite considered lawful, and therefore halal, by Islamic religious norms (food, clothing, cosmetics, finance, etc.). Halal practices are important economic venues and can take different forms, ranging from structures (such as religious tourism agencies to Islamic holy places, Islamic undertakers) to products to be consumed, such as meat. There is a positive choice focused on a market niche in which the entrepreneur has a visible advantage or is forced to enter low-paying sectors rejected by previous incumbents (Jones et al., 1992). Muslim traders rely on their community's growing demand and the increasing preference for specific products (Ma Mung \& Guillon, 1986; G. Simon \& Ma Mung, 1990). Ethnic trade that is oriented towards the Muslim population has relied primarily on its community (Live, 1992; Manço \& Akhan, 1994) and benefited greatly from a network of mutual support (Pécoud, 2012). From this initial community situation, this type of commerce has evolved, simultaneously with the community's growth, towards a greater diversity of activities (Wang \& Lo, 2007).

This paper aims to understand the establishment of Islamic shops while applying several analysis criteria. This research explores the hypothesis of a link between ethnically oriented businesses for Muslim communities and the presence of a mosque. Thus, the Muslim community's presence in the urban area, the presence of mosques, the presence of distribution groups or galleries, and other socio-economic criteria such as income are taken into consideration.

\section{Data and Methods}

To answer the question posed in the introduction, particular attention was paid to the existing literature's research methodologies. The majority of the methods regarding ethnic shops have 
been based on synthesizing pertinent literature (Chiodelli, 2015; Teller et al., 2010) and observation (Devereux et al., 2007; Simon, 2000) or examination (Pieterse, 2003; Shaver \& Flyer, 2000). Nevertheless, other approaches have been used as well, such as surveys through simulations (Head et al., 1994); customer satisfaction (Léo \& Philippe, 2002); super-diversity, which is diversity within minority groups (Yamamura \& Lassalle, 2019); and even conditional logit analysis (Belderbos \& Carree, 2002). These approaches have had several limitations. For instance, observational research is subject to potential subjectivity, which makes a form of quantitative data essential to ensure objectivity. Other approaches that have encountered challenges are those based on literature reviews that have failed to include present and new examples. However, quantitative data face obstacles as well, such as the case of super-diversity and its data collection challenges (Yamamura \& Lassalle, 2019). An additional possible subjective method is customer satisfaction, but, in this case, bias can be generated by the sample. It then becomes difficult to differentiate between satisfied and loyal customers. These methods have both advantages and disadvantages that have limited researchers' findings. The approach introduced in our study took these constraints into consideration.

This study follows a retrospective analysis approach to explore the impact of the mosque on the social and functional fabric of an urban area. It is challenging to determine which Islamic shops were established first in a neighborhood containing mosques. However, what is essential is that the first mosques were accompanied by or were often close to commercial activities (grocery stores, halal butchers, and Islamic bookstores) (Dassetto, 2013). Therefore, this study focuses on three different contexts. The first is an urban area containing Islamic places of worship; the second is an urban area containing a Muslim community and ethnic businesses but lacking a mosque; and the third is an urban area containing a shopping center in order to determine whether such a structure attracts or drives out ethnic businesses. For each selected sample, a set of buffers (ranging from 100 to 1000 meters) was placed around it to measure this type of commerce's emergence. These businesses were identified and classified based on on-site observations and interviews.

\subsection{Definitions of variables (data and descriptive statistics)}

This research focuses on the city of Liège, a French-speaking city of Belgium, the capital of the province of Liège, and the economic capital of Wallonia. The municipality of Liège covers 69.39 $\mathrm{km}^{2}$ and has a population of 195,875 inhabitants, with a population density of 2822.81 inhabitants $/ \mathrm{km}^{2}$. This makes Liège the fourth most populated city in the country (Liège, 2013). The city has geostrategic assets, with a Belgian inland port that ranks first in the country and third in Europe. A motorway network and rail links (TGV) connect Liège to major cities, such as Paris, Amsterdam, Aachen, Brussels, and Cologne. Liège is also well connected to the European Union's 
main cities. Liège has many religious buildings, including churches, mosques, and a synagogue, that manage to coexist.

The establishment of the Muslim religion in the city is historical. Before 1971, Liège had no Islamic structure or prayer hall. In 1971, the priest of Saint Andrew's Church offered a room for early Muslims in the city to practice their prayers. They were all first-time migrants from Morocco who immigrated to work in Belgium. The "Masjid Drouj" was the first Muslim worship place in the city (El Boujjoufi, 2018). A few years later, this minority of migrants was growing. New Muslim migrants arrived, and space became minimal to accommodate them all as they practiced prayer at the same time, especially since the room condition had deteriorated. This was a decisive factor in finding another more extensive and more comfortable place for prayers. Today, Liège city has fourteen mosques disseminated across the city.

\subsection{Selected Samples}

Thirteen mosques in Liège were selected to form the first sample (1). The selected mosques are AL-Mowahidine, As-Salam, As-Sabil, Al-Itissam, Al-Imane, Al-Mouhsinine, Al-Mousslimoune, Bonne Compagnie, Bilal, At-Taqwa, El-Fath, Madani, and Merkez. They are located in residential, school, and commercial contexts (see fig. 1). Emerging commercial activities revolving around mosques (e.g., bakeries, bookstores, shops, cafés, and restaurants) and their interactions were explored. In addition to this first sample, two other urban areas containing ethnic businesses without a mosque nearby are included. These are the Guillemins and Sainte Walburge districts (a district containing a Muslim population [see map], linked to the history of migration) (sample 2), and finally, an urban area containing a shopping center (sample 3) was examined: the district of Angleur. Since no data on ethnic trades in Liège exist, it was essential to carry out a field survey to establish a database on the subject. 


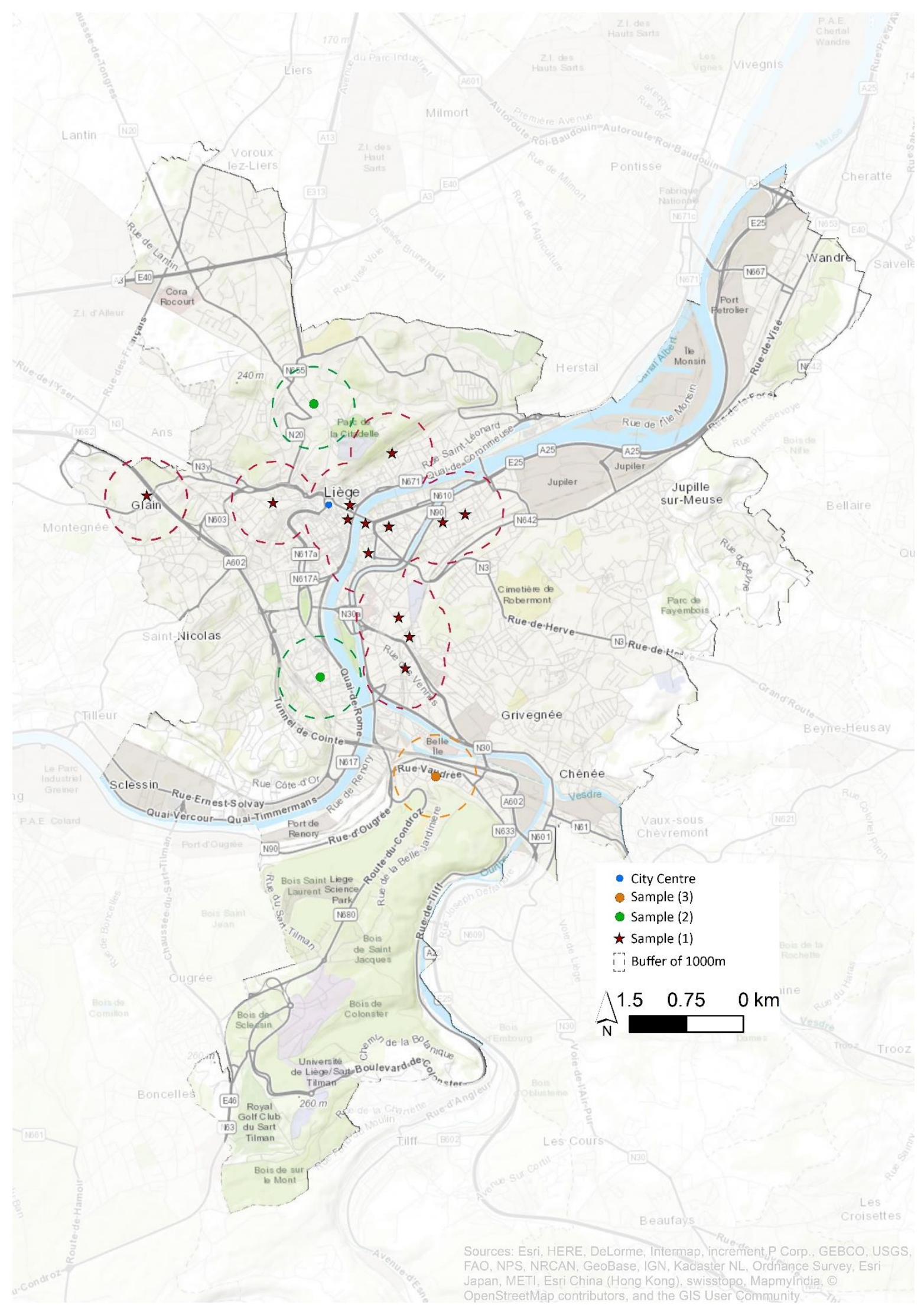

Fig. 1: The different samples selected. 


\subsection{Data-collecting procedure}

To set clear and strict criteria and determine an ethnic-religious category of an Islamic shop (oriented towards the Muslim community), a review of the abovementioned definitions was conducted. In the same vein as ethnic businesses in general, this study uses three criteria to define and identify Islamic shops: the trader, the clientele, and the offered products. To do so, in-situ observations and brief interviews with traders were performed as the basis of this exploratory work. After identifying the three samples, we explored the area. The survey began in January 2019 and lasted three months. The interviews took place on weekdays between 10 am and 4 pm. The study's objective was explained to each trader, and participants were informed that the responses were anonymous and only within the framework of the study. Most traders did not hesitate to answer our questions. All of the stores present in this study area were classified in a table, which included the address, the type of activity, the name of the trader, the name of the store, the presence or absence of an ethnic Islamic sign or brand inside or outside the store, the language spoken in the store, the customers who frequent the store, and, if possible, the ethnic or religious origin. Identifying the trader's origin may raise a considerable number of questions and exceptions because "native" Belgian Muslim traders develop commercial activities oriented towards the Muslim community. Thus, all internal and external ethnic signs were considered (sign, writing language, spoken language, sold products, etc.).

This work allowed us to identify 1185 commercial cells. Based on the criteria established for determining Islamic shops, 414 trades comprised our census.

\subsection{Location of the Muslim population in Liège city}

It is very interesting to cross-reference the presence of Muslim communities at the city level with mosques' establishment. This cross-tabulation has never been done in Belgium with statistical data. Indeed, the state cannot collect data on political opinions, religion, ethnic origin, or language use. To address this lack of statistical data and to be able to approximately map the settlement of Muslim communities in the city, we relied on statistical data (Statbel, 2013) based on the nationality of origin. The data were processed in parallel with data provided by Liege (2013), which classifies the non-Belgian foreign population by country. This selection is limited to the top 20 nationalities, which have significant representation. Italy ranks first (7921), followed by France in second place (4652), and then Morocco in third place (3757). The latter is, first of all, a country outside of Europe, but what interests us here is that Morocco is a Muslim country. According to the PEW Research Centre (Hackett et al., 2012), 99.9\% of the Moroccan population is Muslim. Continuing the ranking, Turkey comes in fifth place after Spain and is second as a predominantly Muslim country (98\%). For this study, the limitation to the 20 most prevalent 
nationalities of origin allowed us to base our calculation on the five countries that appeared first: Morocco, Algeria (with $97.9 \%$ of Muslims), Tunisia (with $99.5 \%$ of Muslims), Turkey, and Iraq, which ranks 16th (with $99 \%$ of Muslims).

Table (1). The top 20 foreign nationalities domiciled in Liège in 2013. Source: Liège (2013).

\begin{tabular}{|c|l|c|c|}
\hline Ranking & Origin (by nationality) & Number & $\%$ of Muslims in the country \\
\hline 1 & Italy & 7921 & \\
\hline 2 & France & 4652 & \\
\hline 3 & Morocco & 3757 & \\
\hline 4 & Spain & 2790 & \\
\hline 5 & Turkey & 1239 & \\
\hline 6 & Congo & 1208 & \multirow{2}{*}{$98 \%$} \\
\hline 7 & Romania & 1181 & \\
\hline 8 & Cameroon & 815 & \\
\hline 9 & Algeria & 685 & \\
\hline 10 & Netherlands & 586 & \\
\hline 11 & Tunisia & 471 & \\
\hline 12 & PORTUGAL & 432 & \\
\hline 13 & China & 388 & \\
\hline 14 & Guinea & 387 & \\
\hline 15 & Greece & 384 & \\
\hline 16 & Irak & 382 & \\
\hline 17 & Russia & 351 & \\
\hline 18 & Germany & 349 & \\
\hline 19 & Bulgaria & 342 & \\
\hline 20 & Poland & 330 & \\
\hline & & & \\
\hline
\end{tabular}

These data were used to identify the country of origin and religion, to define or estimate the location of the populations of these countries, to compare human and physical settlements (mosques), and to contextualize the presence of Muslim communities at the city level. It should be noted that this is an estimate based on the country of origin. This should be interpreted with care because we did not consider Muslims of Belgian nationality (converted or those originating from a Muslim country) since such data are not available in Belgium.

This attempt allowed us to statistically estimate the geographical distribution of Muslim communities in Liege. A strong concentration of Muslims in Bressoux-Centre (more than 600 
people) was found, followed by, in order: Bonne Nouvelle, I'Espérance, I'Yser, Amercoeur, Droixhe, Maghin, Delin-Hesbaye, le Quai, Sainte-Marguerite, Lduxembourg, Villettes, la Grotte, Sainte-Walberge, Bidaut, Dos-Fanchon, Saint-Christophe, Jean De Wilde, Bonne-Flamme, and Seeliger.

Muslims are concentrated in some urban regions primarily due to the history of migration itself. Belgium's high demand for foreign labor in the early 1960s led migrants to settle in certain urban space areas, sometimes far from the center (Maréchal et al., 2007). This settlement occurred near places of employment, which tended to be located on the city's outskirts. These areas were often reserved for the bourgeoisie and occupied by historic buildings, which allowed shops and workshops to settle outside the city and connect to river and train lines. Muslim immigration has been concentrated in a privileged manner in urban areas according to the functions assigned to Muslim origin populations when migrants first arrived (Dassetto, 1996). The regular distribution of Muslim communities is a remnant of Maghreb and Turkish immigration (Van Kempen, 2005). This settlement of Muslim communities tends to occur in the urban space according to their origin, language, customs, and family ties (Gale, 2008; Peach, 2006). The integration of migrants into a host society is a long process that depends on many factors and requires regular interaction between the former and the latter. It is a process that depends on the individual trajectory and contacts of each member with the host society. For reasons such as language, lack of knowledge of the host country's culture, or very different customs from those practiced in the country of origin, these people choose to settle with fellow citizens of the same origin or even the same region. This is the case for the Turkish and Moroccan communities in Belgium (Ettourki et al., 2017). In Liege, for example, according to the in-situ observations and interviews, southern Moroccans tend to settle in Glain, where they have developed a mosque (Bilal). In contrast, northern Moroccans tend to settle in Bressoux and Outremeuse and have developed five mosques.

\subsection{Commercial classification}

Once the businesses were located and identified based on in-situ surveys and interviews with traders, they were classified. According to the "Atlas du commerce de Wallonie" (Devillet et al., 2014), five classes were considered: regular trade (including general food and specialized food: grocery stores, supermarkets, bakeries, butcher's shops, fruits, and vegetables, etc.), light semiregular trade (including clothing, personal care, decoration, and multimedia: clothing shops, perfume shops, hairdressers, decoration articles, CD-DVD, cameras, etc.), heavy semi-regular trade (including furniture, household appliances, DIY, transport and animals: kitchen, bedding, machines, construction materials, gardening articles, motorbikes, animal articles, etc.), Horeca (including hotels, cafés, restaurants, and snack bars), and services. The other parameter analyzed 
in this research is whether the trade is oriented towards the Muslim community (Islamic shop), and this was cross-referenced with different socio-economic variables and parameters.

Among the 1185 surveyed businesses, Horeca is the most prevalent (396). In second place is light semi-regular trade (370), followed by regular trade (261). In fourth place is heavy semi-regular trade (121), and last is services (38). 


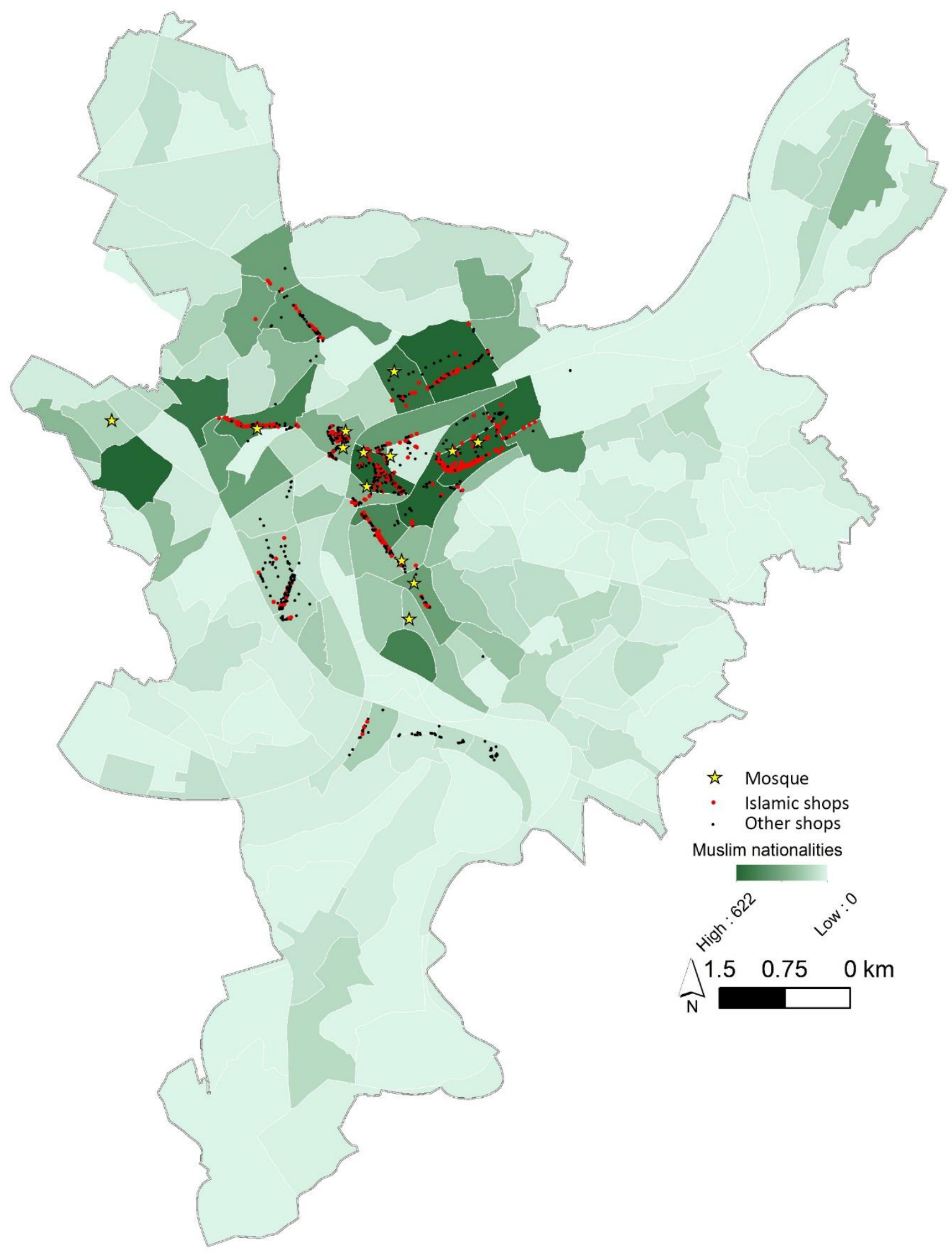

Fig. 2: Islamic shops surveyed and Muslim nationalities' concentration per statistical sector (statistically) in Liège in 2013 (percentages of the total population). Source: Author's calculations. 


\subsection{Logistic regression model}

After identifying the focus of this research, defining the objectives, and presenting the conceptual framework underlying this paper, this section aims to outline the methodological guidelines followed in the research.

This study uses a logistic regression model (logit) to examine the relationship between mosques and the emergence of Islamic shops. Logistic regression (logit) models are widely used in urban and spatial analysis studies (Hu \& Lo, 2007; Mustafa et al., 2021). They predict the outcome of categorical variables using a set of quantitative predictors. Logit can include geophysical as well as socio-economic factors. The model's ability to include as many factors as necessary allows us to better understand the main drivers behind the phenomenon being studied. Logit uses a logistic function to model the relationship between a binary dependent variable and a set of independent (explanatory) variables. The dependent variable is the business's ethnicity (non-Muslim: 0; Muslim: 1), and the explanatory variables are Euclidean distances to the selected mosques, bus stops, Liege city center, major retail corporations, and shopping centers; median income; number of Belgian inhabitants; number of Muslim inhabitants; number of other inhabitants; elevation (relative to sea level); and slope. The locations of mosques, bus stops, major retail corporations, and shopping centers were digitized. Then, the median income, the number of Belgian inhabitants, the number of Muslim inhabitants, and the number of other inhabitants at the statistical sector level (the finest possible scale) were calculated. All of these variables were made available by Statbel (2013).

Elevation and slope angles were calculated based on DEM data provided by the Belgian National Geographic Institute. As the data were measured in different units (meters, numbers, etc.), we standardized all values before running the logit model. This analysis also used a random approach to minimize the spatial autocorrelation effect that may bias the logit analysis outcome (Mustafa et al., 2018).

The logit model's goodness-of-fit was evaluated with the area under the curve (AUC) of the relative operating characteristic (ROC) method. The ROC is an excellent method to estimate a logit model's quality (Hu \& Lo, 2007). A ROC value of 0.5 means utterly random discrimination and 1 means perfect discrimination.

\section{Results and discussions}

The criterion for the location of Islamic shops was cross-referenced with other variables, such as distance from the center, proximity to supermarkets and shopping malls, distance from the mosque, socio-economic variables (immigration, income nationalities, etc.), and bus accessibility data. This allowed us to determine whether a meaningful relationship was present. 
Table (2). Logistic regression model showing the location of Islamic shops influenced by a mosque's presence. Source: Author's calculations.

\begin{tabular}{|l|r|}
\hline Intercept/Variables & Coefficient \\
\hline (Intercept) & -1.7251 \\
\hline Dist. mosques & $-2.3657^{* *}$ \\
\hline Dist. bus stops & -0.2846 \\
\hline Dist. gallery & $1.0639^{* *}$ \\
\hline Dist. City center & 0.0297 \\
\hline Dist. supermarket & -0.0869 \\
\hline Median income & -0.1285 \\
\hline Other nationalities & $-0.2920^{* *}$ \\
\hline Muslim nationalities & $0.2891^{* *}$ \\
\hline Elevation & $0.5199^{*}$ \\
\hline Slope & -0.1611 \\
\hline
\end{tabular}

Signifiance at $* * P<0.01$ and $* P<0.1$.

The logit analysis shows a significant negative relationship between distance to mosques and Islamic shops' locations. This means that these stores are more likely to be located near mosques. Support for this result can be found in Dassetto's research (2013), which points out that the first European mosques were accompanied by commercial activities: grocery stores and or halal butchers. Distance from the city center and shopping centers (galleries) and elevation have a statistically significant relationship with the location of Islamic shops, but it is much less important than the distance from mosques. Distance from the city center is positively related to the location of Islamic shops, indicating that the majority of ethnic trades are located outside of the city center. This relationship supports the assertion of several researchers that most European mosques are located in marginal areas, far from the center and in the periphery (Arab, 2013; Gale, 2008; Kuppinger, 2011). The influence of Muslim nationalities is positive but not significant compared to other variables. Today, the locations of Muslim communities are much more dispersed than mosques (Fig. 2), which then had greater explanatory power. Settling next to workplaces or next to mosques, as was the case for newcomers, has evolved among new Muslim generations. The choice of location for Muslims today is influenced by criteria such as accessibility to transportation, proximity to the city center and stores, proximity to reputable schools, and access to recreational activities such as parks and playgrounds. The AUC of the logit model is 0.72. AUC values higher than 0.70 are considered to be a reasonable fit (Cammerer et al., 2012; Jr \& Lemeshow, 2004). 
This result shows that Islamic shops are located near mosques, prompting us to identify the trade types that gravitate around them. Different buffers sizes, ranging from 100 to 1000 meters, around each mosque were used, intending to explore the dominant type of businesses within each buffer and even determine whether this representation varies with increasing distances from the mosque. 


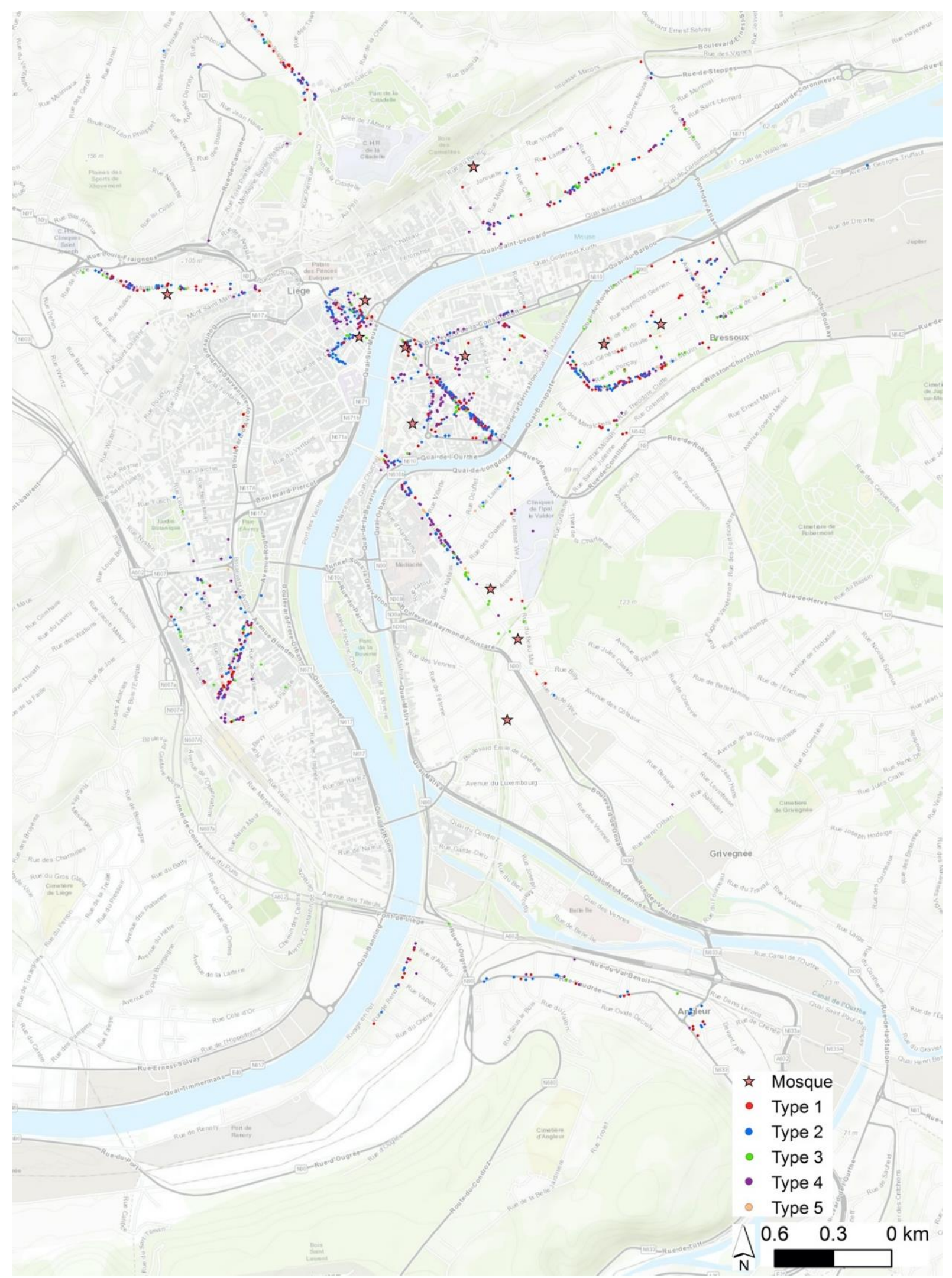

Fig. 3: Distribution of different commerce types. Source: Author's calculations. 
The analysis shows that light semi-regular trade (type 2) is predominant up to a radius of $250 \mathrm{~m}$ around the mosque. In this type of commerce, we find everything related to personal care, i.e., clothing stores, perfume shops, and hairdressers, but also retail related to decoration and entertainment. It is important to note that several ethnic hairdressing and beauty salons were surveyed around the mosques during the interviews and in-situ observations. The second dominant type of business is Horeca (type 4), with cafés, restaurants, and snack bars. Hotels, which are among this type of establishment, were identified only twice in our samples. However, the difference between business types (2) and (4) is marginal. The third type is the regular trade (type 1), including general and specialized food trade, grocery stores, supermarkets, bakeries, butchers (and halal), fruits and vegetables, etc. This business type (1) maintains the same prevalence, even within a radius of 1000 meters, whereas the two main types of shops, (2) and (4), reverse their frequencies in the 100- and 250-meters radius. Horeca (4) takes first place, and light semi-regular trade (2) ranks second. However, this time, the difference is significant. The presence of heavy semi-regular trade, which ranks fourth (type 3), and services (type 5), which ranks fifth, is not significant. This may be due to the areas chosen for our sample but also to the fact that several mosques and ethnic shops in Europe are located in marginal areas away from the city centers and on the outskirts: industrial areas that are difficult to access (Arab, 2013; Kuppinger, 2011) or residential areas.

The strong presence of Horeca (type 4) in the mosques' vicinity can be explained by the importance of the first European mosques in Muslims' lives. Indeed, the mosque was considered a "halal café", where tea was always served for free and where exchange, mutual help, and support were provided. The existence of these places of worship also allowed for discussions and meetings to help members of the community in their daily lives as a real social service (Dassetto, 1996). Today, the cafés around the mosques partly play this role while providing opportunities for meetings, exchanges, and entertainment. Thus, cafés or restaurants allow for the faithful to meet once the prayer is over and serve as an extension to the mosque's space in the city. Regarding the presence of light semi-regular trade (type 2), primarily comprising personal care companies, we can link this to the historical establishment of hammams and hairdressers near mosques in Muslims' cities (Asli \& Jazi, 2008), where importance is accorded to body care. This importance is also explained by the Muslim religion itself, which encourages the practitioner to take care of himself and look beautiful and elegant before going to the mosque or in everyday life in general. 


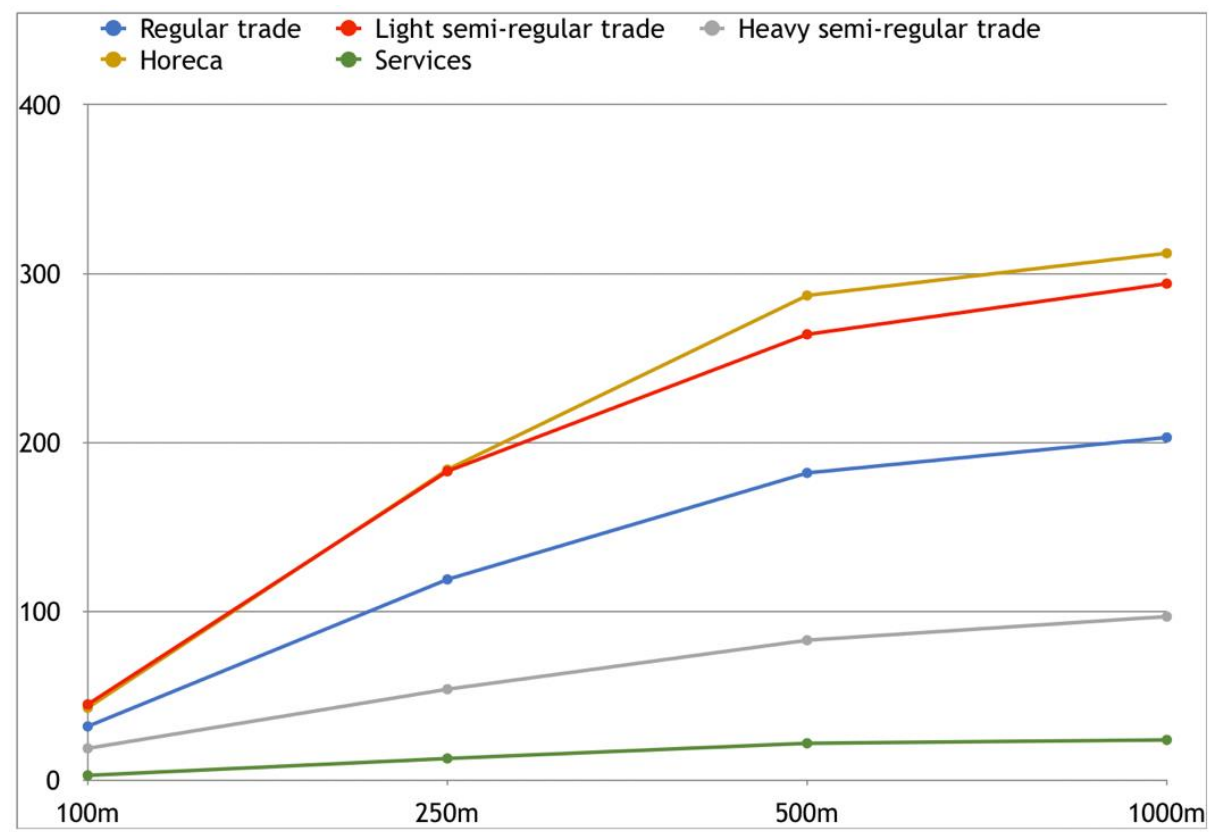

Fig.4: Graph showing the evolution of the different types of shops according to the buffers.

In a commercial context, competition is particularly complex. Whereas some businesses tend to prefer locations associated with less competition, other companies prefer to set up near their immediate competitors in order to benefit from their visibility. Competition does not solely mean individual competition between stores. It is more generally related to competition between types of businesses, between locations, or even between different clienteles (Wayens, 2006). Thus, certain types of businesses tend to be grouped while ignoring competition's disadvantages. This grouping instead of isolation may provide better results. However, competition can take different forms. For this research, two types are very important to address. The first is that of competition or complementarity between urban businesses. If each business of one type sells almost the same goods as others, it cannot distinguish itself from competitors. Nevertheless, if there is a sufficient difference in assortment, the customer will be able to find all necessary goods in the same area, a phenomenon defined as complementarity. This makes it possible to have a commercial concentration in an urban area and to constitute an "open-air gallery" where the customer can find what he seeks while remaining close to the place of worship. The second type is competition between businesses of the same type. Different shops are set up in an urban area on the street or in the same space. This can generate customer loyalty to businesses (Grimmeau, 2006). The significant impact of mosques on establishing new businesses in the surrounding urban space, mainly Islamic shops, reinforces the existence of an urban ecosystem revolving around mosques. This leads us to consider the mosque as an architectural device that articulates the communalspiritual space and public space as a true space of transition. As such, the logic of "inside and outside" is transcended, and the mosque devotee organizes his travel to the mosque while taking 
advantage of the existence of commercial, educational, and social activities in this spiritual space to buy his food, go to the hairdresser's, and then eat and have coffee with his friends.

The mosque, a beacon of orientation for Muslims, can be considered a new structuring element in the urban environment but also as a new centrality in the contemporary European city. By centrality, we mean the action of an element on its immediate urban environment in terms of the organization of traffic flows, symbolic representations, or attractions of related activities, such as commerce or housing (Merlin \& Choay, 1988). The results of this study, applied to a Belgian city, perhaps similar to other European cities. The collective facility of the mosque plays the same role in other European countries that have a similar migratory history (Dassetto, 2013) and where the development of mosques has proceeded through the same phases.

\section{Conclusions and Future work}

This study aimed to understand the role of the mosque location within European cities, with a particular focus on its impact on Islamic shops. Using a logistic regression model (logit), an exploration was conducted on the relationship between the locations of stores providing goods and services to Muslims (Islamic shops) and a set of variables, including distance from the city center, proximity to supermarkets and shopping malls, distance from the mosque, socioeconomic variables (immigration, income, nationalities, etc.), and public transport data.

The logit analysis showed a remarkable influence of the mosque on the location choice of Islamic shops. Distance to the city center and shopping centers (galleries) and elevation have a statistically significant relationship with Islamic shops' locations, but the significance is far less than that of mosques' presence. The mosque, a guiding light for Muslims, is a structuring element in the urban environment, a collective facility in its own right, which is organizing the urban fabric in which it is inserted. The results of this article confirm that the mosque has a powerful influence on the location of Islamic shops. Indeed, ethnic economic activities are generating specific urban ecosystems that develop within European cities and are associated with specific landmarks and practices. Such urban ecosystems constitute an important business opportunity for Muslim investors, as they rely on the growing demand of the Muslim community and the increasing attractiveness of specific products (halal label).

The results show that the concentration of populations from Islamic countries does not have an influence comparable to that of the presence of mosques when considering the location of Islamic shops. However, it has to be acknowledged that the location of mosques was initially influenced by the history of migration itself and the concentration of Muslim populations in some specific urban areas. 
The other factor analyzed in this paper is the types of Islamic shops revolving around mosques. By drawing buffers around mosques, some businesses with a strong presence were identified. Type (4), called "Horeca" (cafes, restaurants, and snacks), and type (2), called "Light semi-regular trade " (mainly personal care), are the two most frequently encountered shops. The symbolic value can explain the prevalent presence of Horeca (type 4) surrounding mosques. The first mosques built in European cities were considered places for mutual assistance and support. They provide opportunities for discussions and meetings to help members of the Muslim community in their daily lives.

For future work, we are interested in applying this methodology to other European cities in order to better identify the differences in the mosque's role from one urban context to another and to measure the evolution of Islamic shops over time while analyzing their concentration in urban areas. 


\section{References}

Allen, C., Amghar, S., Amiraux, V., Boubekeur, A., Choudhury, T., Emerson, M., Godard, B., Karich, I., Rigoni, I., \& Roy, O. (2007). European Islam: Challenges for society and public policy. EUROPEAN ISLAM: CHALLENGES FOR SOCIETY AND PUBLIC POLICY, Samir Amghar, Amel Boubekeur, Michael Emerson, eds., CEPS Paperbacks.

Allievi, S. (2003). Sociology of a newcomer: Muslim migration to Italy-religious visibility, cultural and political reactions. Immigrants \& Minorities, 22(2-3), 141-154.

Allievi, S. (2009). Conflicts over Mosques in Europe: Policy issues and trends. Alliance Publishing Trust.

Allievi, S. (2010). Immigration and cultural pluralism in Italy: Multiculturalism as a missing model. Italian culture, 28(2), 85-103.

Allievi, S. (2014). Immigration, religious diversity and recognition of differences: The Italian way to multiculturalism. Identities, 21(6), 724-737.

Arab, P. T. (2013). Mosques in the Netherlands: Transforming the Meaning of Marginal Spaces. Journal of Muslim Minority Affairs, 33(4), 477-494.

https://doi.org/10.1080/13602004.2013.866349

Asli, F., \& Jazi, R. (2008). "Le Hammam» à travers des manuscrits et autres ouvrages anciens de la littérature médicale arabe. Revue d'histoire de la pharmacie, 95(358), 177-188.

Azam, J.-P., \& Gubert, F. (2006). Migrants' remittances and the household in Africa: A review of evidence. Journal of African Economies, 15(suppl_2), 426-462. 
Barou, J. (1999). L'Arabe du coin et le Chinois du quartier, ou le commerce « ethnique » au service de tous. Hommes \& Migrations, 1221(1), 24-31.

https://doi.org/10.3406/homig.1999.3381

Battegay, A. (2011). Les commerces ethniques et le milieu urbain. Migrations Société, 136, 137-152. https://doi.org/10.3917/migra.136.0137

Behloul, S. M., Leuenberger, S., \& Tunger-Zanetti, A. (2014). Debating Islam: Negotiating religion, Europe, and the self. transcript Verlag.

Belderbos, R., \& Carree, M. (2002). The Location of Japanese Investments in China: Agglomeration Effects, Keiretsu, and Firm Heterogeneity. Journal of the Japanese and International Economies, 16(2), 194-211. https://doi.org/10.1006/jjie.2001.0491

Cammerer, H., Thieken, A. H., \& Verburg, P. H. (2012). Spatio-temporal dynamics in the flood exposure due to land use changes in the Alpine Lech Valley in Tyrol (Austria) I SpringerLink. https://link.springer.com/article/10.1007/s11069-012-0280-8

Cesari, J. (2005a). Mosque conflicts in European cities: Introduction. Journal of ethnic and Migration Studies, 31(6), 1015-1024.

Chiodelli, F. (2015). Religion and the city: A review on Muslim spatiality in Italian cities. Cities, $44,19-28$.

Conti, B. (2012). L'émergence de l'islam dans l'espace public. Archives de sciences sociales des religions, 158, 119-136.

Conti, B. (2016). Islam as a new social actor in Italian cities: Mosque controversies as sites of inclusion and separation. Religion, State \& Society, 44(3), 238-257.

Dassetto, F. (1996). La construction de l'islam européen. Approche socio-anthropologique. 
Dassetto, F. (2013). L'Iris et le Croissant: Bruxelles et I'Islam au défi de la co-inclusion. Presses universitaires de Louvain.

Devereux, M. P., Griffith, R., \& Simpson, H. (2007). Firm location decisions, regional grants and agglomeration externalities. Journal of Public Economics, 91(3), 413-435. https://doi.org/10.1016/j.jpubeco.2006.12.002

Devillet, G., Jaspard, M., \& Vazquez Parras, J. (2014). Atlas du commerce en Wallonie. Structures, dynamiques, comportements spatiaux des consommateurs. Presses universitaires de Liège.

El Boujjoufi, M. (2018). L'inscription socio-spatiale des mosquées dans l'espace public d'une ville européenne (Liège comme cas d'étude). Mémoire de fin d'études.

Ettourki, K., De Schutter, S., \& Goddeeris, I. (2017). 3. Historical research on Moroccan migration in Belgium. Moroccan Migration in Belgium: More than 50 Years of Settlement, 1, 61.

Fadil, N., Manço, U., \& Kanmaz, M. (2010). Belgium. In Yearbook of Muslims in Europe, Volume 2 (p. 67-88). Brill.

Gagnon, J. E., \& Germain, A. (2002). Espace urbain et religion: Esquisse d'une géographie des lieux de culte minoritaires de la région de Montréal. Cahiers de géographie du Québec, 46(128), 143-163.

Gale, R. (2008). Locating religion in urban planning: Beyond 'race'and ethnicity? Planning, Practice \& Research, 23(1), 19-39.

Galembert, C. de. (1995). De L'inscription de l'Islam dans l'espace urbain. Les Annales de la recherche urbaine, 68, 178-188. 
Germain, A., Liégeois, L., \& Hoernig, H. (2008). Les espaces publics en contexte multiethnique. Religion, visibilité et pasteurisation. Les nouveaux territoires de l'ethnicité, 157-181.

Göle, N. (2011). The public visibility of Islam and European politics of resentment: The minaretsmosques debate. Philosophy \& Social Criticism, 37(4), 383-392.

Grimmeau, J.-P. (2006). Commerce de détail, concurrence et géographie. Belgeo. Revue belge de géographie, 1-2, 1-8.

Guillon, M. (1986). Les activités commerciales et artisanales. Guillion-Taboada Leonetti, Le Triangle de Choisy, un quartier chinois a Paris, Ciemi L'Harmattan.

Haberfellner, R., Betz, F., Böse, M., \& Riegler, J. (2000). Ethnic Business. Integration vs. Segregation. Endbericht. Wien, ZSI, Retrieved from: https://www. zsi. at/attach/EthnicBusiness_2000.pdf, 5(02), 2016.

Head, K., Ries, J. C., \& Swenson, D. L. (1994). The attraction of foreign manufacturing investments: Investment promotion and agglomeration economies. National Bureau of Economic Research.

Hu, Z., \& Lo, C. P. (2007). Modeling urban growth in Atlanta using logistic regression. Computers, Environment and Urban Systems, 31(6), 667-688.

Jones, T., Barrett, G., \& McEvoy, D. (2000). Market Potential as a Decisive Influence on the Performance of Ethnic Minority Business. In J. Rath (Éd.), Immigrant Businesses: The Economic, Political and Social Environment (p. 37-53). Palgrave Macmillan UK. https://doi.org/10.1057/9781403905338_3 
Jones, T. P., Mc EVOY, D., Body-Gendrot, S., Ma Mung, E., \& Hodeir, C. (1992). Ressources ethniques et égalité des chances: Les entreprises indo-pakistanaises en Grande-Bretagne et au Canada. Revue européenne des migrations internationales, 8(1), 107-126.

Jonker, G. (2005). The Mevlana mosque in Berlin-Kreuzberg: An unsolved conflict. Journal of Ethnic and Migration Studies, 31(6), 1067-1081.

Jr, D. W. H., \& Lemeshow, S. (2004). Applied Logistic Regression. John Wiley \& Sons, 494.

Kaplan, D. H. (1997). The creation of an ethnic economy: Indochinese business expansion in Saint Paul. Economic Geography, 73(2), 214-233.

Kesteloot, C. (1987). The residential location of immigrant workers in Belgian cities: An ethnic or socio-economic phenomenon? Erdkundliches Wissen, 84.

Kuppinger, P. (2011). Vibrant mosques: Space, planning and informality in Germany. Built Environment, 37(1), 78-91.

Landman, N., \& Wessels, W. (2005). The visibility of mosques in Dutch towns. Journal of Ethnic and Migration Studies, 31(6), 1125-1140.

Lefebvre, H. (1970). From rural to urban. From rural to urban.

Léo, P.-Y., \& Philippe, J. (2002). Retail centres: Location and consumer's satisfaction. Service Industries Journal, 22(1), 122-146.

Liège. (2013). Tableau de bord de la population liègeoise-Ville de Liège. L'Échevinat de l'État civil, des Mairies de Quartier et des Cimetières. https://www.liege.be/fr/viecommunale/administration/liege-en-chiffres/tableaux-de-bord-population/tableau-debord-population-2013.pdf

Light, I., \& Gold, S. (2000). Ethnic economies. 
Live, Y.-S. (1992). Les Chinois de Paris depuis le début du siècle. Présence urbaine et activités économiques. Revue européenne des migrations internationales, 8(3), 155-173.

Ma Mung, G. (2015). Le commerce ethnique dans les espaces marchands de Château Rouge (Paris) et Brixton (Londres). e-Migrinter, 13. https://doi.org/10.4000/e-migrinter.564 Ma Mung, E., Body-Gendrot, S., \& Hodeir, C. (1992). L'expansion du commerce ethnique: Asiatiques et Maghrébins dans la région parisienne. Revue européenne des migrations internationales, 8(1), 39-59.

Ma Mung, E., \& Guillon, M. (1986). Les commerçants étrangers dans l'agglomération parisienne. Revue européenne des migrations internationales, 2(3), 105-134.

Manço, A., \& Amoranitis, S. (2005). Reconnaissance de l'islam dans les communes d'Europe. Actions contre les discriminations religieuses, Paris, Budapest, L'Harmattan, coll. «Compétences interculturelles.

Manço, A, \& Akhan, O. (1994). La formation d'une bourgeoisie commerçante turque en Belgique. Revue européenne des migrations internationales, 10(2), 149-162.

Manço, U., \& Kanmaz, M. (2005). From conflict to co-operation between Muslims and local authorities in a Brussels borough: Schaerbeek. Journal of Ethnic and Migration Studies, 31(6), 1105-1123.

Maréchal, B., Dassetto, F., \& Ferrari, S. (2007). Islam in the European Union: What's at stake in the future?: Rapport de recherche, réalisé pour le Comité Culture et Education du Parlement Européen.

Marín, V. H. (1997). General system theory and the ecosystem concept. Bulletin of the Ecological Society of America, 78(1), 102-104. 
Martiniello, M. (1995). L'ethnicité dans les sciences sociales contemporaines. FeniXX.

Maussen, M. (2006). The governance of Islam in Western Europe: A state of the art report. IMES, Inst. for Migration and Ethnic Studies, University of Amsterdam.

Maussen, M. J. M. (2009). Constructing mosques: The governance of Islam in France and the Netherlands [PhD Thesis]. Amsterdam School for Social Science Research Amsterdam.

Merlin, P., \& Choay-Dictionnaire de l'urbanisme, F. (1988). de l'aménagement. Edition PUF. McLoughlin, S. (2005). The State,'New'Muslim Leaderships and Islam as a'Resource'for Engagement in Britain.

Mustafa, A., Rienow, A., Saadi, I., Cools, M., \& Teller, J. (2018). Comparing support vector machines with logistic regression for calibrating cellular automata land use change models. European Journal of Remote Sensing, 51(1), 391-401.

Mustafa, A., Ebaid, A., Omrani, H., McPhearson, T., 2021. A multi-objective Markov Chain Monte Carlo cellular automata model: Simulating multi-density urban expansion in NYC. Computers, Environment and Urban Systems 87, 101602. https://doi.org/10.1016/j.compenvurbsys.2021.101602

Peach, C. (2006). Islam, ethnicity and South Asian religions in the London 2001 census. Transactions of the Institute of British Geographers, 31(3), 353-370.

Pécoud, A. (2012). Immigration, entreprenariat et ethnicité. Comprendre la création de commerces au sein des populations d'origine immigrée. Métropoles, 11.

Pieterse, J. N. (2003). Social capital and migration: Beyond ethnic economies. Ethnicities, 3(1), 29-58. https://doi.org/10.1177/1468796803003001785 
Peñaloza, L. (2018). Ethnic marketing practice and research at the intersection of market and social development: A macro study of the past and present, with a look to the future. Journal of Business Research, 82, 273-280.

Rossiter, J. R., \& Chan, A. M. (1998). Ethnicity in business and consumer behavior. Journal of Business Research, 42(2), 127-134.

Rudder, V. D. (2002). De l'urbain au social: Le «cycle des relations raciales» (Vol. 18). Université de Poitiers.

Saint-Blancat, C. (2002). Islam in diaspora: Between reterritorialization and extraterritoriality. International Journal of Urban and Regional Research, 26(1), 138-151.

Schinkel, W. (2009). De productie van marginaliteit. The production of Marginality], in De Moskee. Politieke, architectonische en maatschappelijke transformaties [The Mosque. Political, Architectural and Societal Transformations], eds. Ergün Erkoçu and Cihan Bugdaci, Rotterdam: NAi Uitgevers, 70-78.

Schmitt, T. (2003). Moscheen in Deutschland: Konflikte um ihre Errichtung und Nutzung (Vol. 252). Deutsche Akademie für Landeskunde.

Shaver, J. M., \& Flyer, F. (2000). Agglomeration economies, firm heterogeneity, and foreign direct investment in the United States. Strategic Management Journal, 21(12), 1175-1193. https://doi.org/10.1002/1097-0266(200012)21:12<1175::AIDSMJ139>3.0.CO;2-Q

Simon, G., \& Ma Mung, E. (1990). La dynamique des commerces maghrébins et asiatiques et les perspectives du marché intérieur européen. Annales de géographie, 152-172. 
Simon, P. (2000). The Mosaic Pattern: Cohabitation between Ethnic Groups in Belleville, Paris. In S. Body-Gendrot \& M. Martiniello (Éds.), Minorities in European Cities: The Dynamics of Social Integration and Social Exclusion at the Neighbourhood Level (p. 100-115). Palgrave Macmillan UK. https://doi.org/10.1007/978-1-349-62841-4_8

Statbel. (2013). Statbel (Direction générale Statistique-Statistics Belgium). Données statistiques par secteur statistique. statbel@economie.fgov.be

Teller, C., Elms, J. R., Thomson, J. A., \& Paddison, A. R. (2010). Place marketing and urban retail agglomerations: An examination of shoppers' place attractiveness perceptions. Place Branding and Public Diplomacy, 6(2), 124-133.

Torrekens, C. (2007). Concentration of Muslim populations and structure of Muslim associations in Brussels. Brussels Studies. La revue scientifique électronique pour les recherches sur Bruxelles/Het elektronisch wetenschappelijk tijdschrift voor onderzoek over Brussel/The e-journal for academic research on Brussels.

Torrekens, C. (2009). L'espace de la mosquée à Bruxelles: Nouveaux liens sociaux et investissement politique. Revue des mondes musulmans et de la Méditerranée, 125, 143-158.

Van Kempen, R. (2005). Segregation and housing conditions of immigrants in Western European cities. Cities of Europe: Changing Contexts, Local Arrangements, and the Challenge to Urban Cohesion, 190-209.

Waldinger, R. (1995). The 'other side'of embedded ness: A case-study of the interplay of economy and ethnicity. Ethnic and racial studies, 18(3), 555-580. 
Waldinger, R. D., Aldrich, H., \& Ward, R. (1990). Ethnic entrepreneurs: Immigrant business in industrial societies (Vol. 1). Sage Publications, Inc.

Wang, L., \& Lo, L. (2007). Immigrant grocery-shopping behavior: Ethnic identity versus accessibility. Environment and Planning A, 39(3), 684-699.

Wayens, B. (2006). Structure et dynamique du commerce de détail bruxellois. Une approche sous l'angle des.

Yamamura, S., \& Lassalle, P. (2019). Approximating entrepreneurial superdiversity: Reconceptualizing the superdiversity debate in ethnic minority entrepreneurship. Journal of Ethnic and Migration Studies, 1-22. 